\title{
Characterization of New Strains of Clostridium thermocellum and the celA Gene from a Strain
}

\author{
Naotaka Kurose, Junji Yagyu, Mika OHMOrI, \\ Miyuki Matsumoto, ${ }^{*}$ Katsuaki Ohsato, ${ }^{*}$ Tomiaki Yamada, \\ Masahiro UCHIDA and Akira OBAYASHI \\ Central Research Laboratories, Takara Shuzo Co., Ltd., \\ Seta 3-4-1, Otsu, Shiga 520-21, Japan \\ * Biotechnology Research Department, Research \& Development Division, \\ JGC Corporation, Bessho 1-14-1, Minami-ku, \\ Yokohama, Kanagawa 232, Japan
}

Received May 18, 1989

\begin{abstract}
Two strains of thermophilic cellulolytic anaerobes, Nos. 138 and 183, were isolated from soil and compost, respectively, and identified as Clostridium thermocellum, based on their morphological, physiological and genetic characteristies. These two isolates decomposed cellulose more efficiently than the type strain, $C$. thermocellum ATCC 27405. The celA gene of strain No. 138 was cloned onto vector plasmid pBR322 and the hybrid plasmids obtained were introduced into Escherichia coli cells. The cleavage map of the cloned $c e l \mathrm{~A}$ gene and the extent of $\mathrm{CM}$-cellulase expression of the cloned gene in $E$. coli were the same as those of the $c e l \mathrm{~A}$ gene from ATCC 27405.
\end{abstract}

The cellulosic biomass, which is aboundant and renewable, is an imporant resource for the production of useful chemicals, such as alcohol and various organic acids. Thus, microbial cells with high cellulosic biomass-degrading activity have been extensively screened for. Cellulase produced by Trichoderma reese $i$ and similar fungi is a typical enzyme much studied for possible practical application to the production of ethanol. In addition to fungal microbes with high cellulase-producing activity, many cellulolytic bacteria have also been isolated.Clostridium thermocellum cells secrete cellulase and convert cellulose directly to ethanol at high temperatures. Thermostable cellulases produced by thermophiles such as $C$. thermocellum are of particular interest, and many reports on the isolation of thermophilic cellulolytic anaerobes and their cellulases, ${ }^{1 \sim 6)}$ and cellulase genes ${ }^{79)}$ have been published.

Recently, we isolated two strains of thermophilic cellulolytic clostridia for use for the direct production of ethanol from the cellulosic biomass. In this paper, we describe the isolation and characterization of these cellulo- lytic thermophiles that grow under anaerobic conditions. The cloning of the celA gene from one isolate and its expression in E. coli cells were also studied.

\section{Materials and Methods}

Strains. The strains used were $C$. thermocellum Nos. 138 and 183, isolated from soil and compost, respectively; $C$. thermocellum ATCC 27405 and ATCC 31549 were used for reference. Escherichia coli strains JM83, C600 and $\mathrm{HB} 101$ were used as host cells for the transformation of the celA gene. Plasmid pCT 104 containing the celA gene of $C$. thermocellum was a gift from Prof. Aubert (Institut Pasteur, France).

Culture conditions. Thermophilic anaerobic cells were grown at $60^{\circ} \mathrm{C}$ under strict anaerobic conditions $\left(\mathrm{N}_{2}\right.$ gas exchange) in $\mathrm{GS}$ medium ${ }^{10}$ containing cellulose as the sole source of carbon. For the cellulolytic clostridia, DSM medium $^{11)}$ and $\mathrm{K}$ medium ${ }^{12)}$ modified with DSM medium were used, which contained cellulose or cellobiose. E. coli cells were grown in L-broth. For the selection and cultivation of $E$. coli transformants, ampicillin $(50 \mu \mathrm{g} / \mathrm{ml})$ was added to the L-broth.

Analyses. The ethanol, acetic acid and lactic acid produced in the broth were assayed by gas chromatography. 
Glucose was measured enzymatically with a Glucostat (Fujisawa Pharmaceutical Co., Japan). The reducing sugar concentration was measured with 3,5-dinitrosalicylic acid according to the method described by Miller. ${ }^{13)}$

Measurement of the GC content. Whole-cell DNA of the clostridia was extracted by the alkaline extraction procedure of Birnboim and Doly. ${ }^{(4)}$ The guanosine + cytosine (GC) content of the DNA was measured with a DNA-GC kit (Yamasa Shoyu Co., Ltd., Japan). The DNA decomposed by nuclease $P_{1}$ was measured as dAMP, dGMP, dCMP and dTMP by HPLC on a Lichrosorb RP-18 column.

DNA homology. Whole-cell DNA of C. thermocellum ATCC 27405 extracted by the above procedure was nicked with DNase I and some of the nucleotides were replaced with radioactive nucleotides, $\left[{ }^{3} \mathrm{H}\right] \mathrm{dTTPs}$. Nick-translated DNA of strain ATCC 27405 was hybridized with the DNA of strains Nos. 138 and 183, and ATCC 27405, which was fixed on a membrane filter. The radioactivity retained on the filters was measured with a scintillation counter. The amount of radioactivity in the homologous filters was taken as $100 \%$ homology and compared with the activity of the heterologous filters.

Enzyme assay. Clostridial cells were grown to the late$\log$ phase in $\mathrm{K}$ medium containing $1 \%$ cellulose at $60^{\circ} \mathrm{C}$. The culture filtrate was used for assaying CM-cellulase and avicelase activities. The collected cells were suspended in $0.1 \mathrm{M}$ potassium phosphate buffer $(\mathrm{pH} \mathrm{7.0)}$ and then sonicated at $90 \mathrm{kHz}$ for $30 \mathrm{~min}$ at $0^{\circ} \mathrm{C}$ in a Kubota Model $200 \mathrm{M}$ Insonator. The sonicates were centrifuged and the clear supernatants were used for assaying $\beta$-glucosidase activity. $E$. coli cells carrying plasmid DNA were grown overnight in L-broth containing $50 \mu \mathrm{g} / \mathrm{ml}$ ampicillin. The cells were collected by centrifugation, suspended in $\mathrm{PC}$ buffer ( $50 \mathrm{mM} \mathrm{K}_{2} \mathrm{HPO}_{4}$ and $12.5 \mathrm{~mm}$ citric acid, $\mathrm{pH} 6.3$ ) and then sonicated at $90 \mathrm{kHz}$ for $10 \mathrm{~min}$ as described by Cornet et al. ? $^{7}$

CM-cellulase activity was assayed by measurement of the reducing sugars produced. One milliliter of the enzyme solution was added to $1 \mathrm{ml}$ of $1 \% \mathrm{CM}$-cellulose (CMC) dissolved in $0.1 \mathrm{M}$ potassium phosphate buffer $(\mathrm{pH} \mathrm{7.0)}$, followed by incubation at $60^{\circ} \mathrm{C}$ for $1 \mathrm{hr}$. After the mixture had been boiled for $10 \mathrm{~min}$, its reducing sugar concentration was measured by the method described above. For assaying CM-cellulase activity in th crude extract of $E$. coli, $1 \mathrm{ml}$ of a $1.5 \%$ CMC solution in PC buffer was mixed with $50 \mu \mathrm{l}$ of the enzyme solution, and then the mixture was incubated at $60^{\circ} \mathrm{C}$ for $1 \mathrm{hr}$. The reducing sugars formed were measured by the Somogyi-Nelson method. ${ }^{15)}$

Avicelase activity was also assayed by measurement of reducing sugars. One milliliter of the enzyme solution was mixed with $1 \mathrm{ml}$ of $1 \%$ Avicel in PC buffer, followed by incubation at $60^{\circ} \mathrm{C}$ for $3 \mathrm{hr}$

$\beta$-Glucosidase activity was assayed by measurement of the glucose formed. One milliliter of $2 \%$ cellobiose in PC buffer and $50 \mu$ of the enzyme solution were mixed, and then the mixture was incubated at $60^{\circ} \mathrm{C}$ for $30 \mathrm{~min}$. After the reaction mixture had been boiled for $10 \mathrm{~min}$, its glucose concentration was measured with a Glucostat.

Proteins in the culture filtrates and crude extracts of clostridial and $E$. coli cells were determined by the methods of Bradford ${ }^{16)}$ and Lowry et al., ${ }^{17}$ respectively.

Cloning of the cel $A$ gene. Based on the reported base sequence ${ }^{9}$ of th cel A gene from $C$. thermocellum ATCC 27405 , iwo kinds of probe DNAs (each 30 merlons) were synthesized and their $5^{\prime}$ ends were labeled with ${ }^{32} \mathrm{P}$. The cel A gene of strain No. 138 was detected as hybridization of the chromosomal DNA, which was digested with restriction endonuclease $H$ indIII, with the two prove DNAs. The HindIII fragment containing the celA gene was removed from the agarose gel and inserted into the same restriction site of plasmid pUC19.

Chemicals. $\left[{ }^{3} \mathrm{H}\right] \mathrm{dTTP}$ and $\left[\gamma^{32} \mathrm{P}\right] \mathrm{ATP}$ were purchased from Amersham Corp., England. Cellulose (KC-Floc) was purchased from Sanyo Kokusaku Pulp Corp., Japan. Restriction endonucleases and $\mathrm{T}_{4}$ DNA ligase were obtained from Takara Shuzo Co., Ltd., Japan.

\section{Results}

\section{Isolation of cellulose-fermenting thermophilic anaerobes}

Approximately 770 soil and compost samples were individually incubated at $60^{\circ} \mathrm{C}$ in GS medium ( $10 \mathrm{ml}$ of medium/tube) containing $1 \%$ cellulose as the sole source of carbon. A small portion of well-grown cultures was transferred to new medium for enrichment of microbial cells with cellulose-utilizing activity. From two well-grown cultures, single colonies were formed in the agar medium by means of the rolling-tube method, which makes it possible for cells to grow under strictly anaerobic conditions. The resulting colonies contained two or more kinds of cells. To isolate single colonies, ten single cells were picked up from cultures 138-3-1 and 183-1-1, by means of a micromanipulator, under anaerobic conditions and put immediately into $\mathrm{K}$ medium containing $1 \%$ cellobiose. After 2 to 3 days incubation, seven cells from 138-3-1 and five cells from 183-1-1 were found to grow on cellobiose at $60^{\circ} \mathrm{C}$. These 12 cultures were transferred to $\mathrm{K}$ medium containing $1 \%$ cel- 
lulose and incubated again at $60^{\circ} \mathrm{C}$ for 7 days. All seven cultures (138-A to $G$ ) from culture 138-3-1 produced ethaol at almost the same concentration (about $0.11 \mathrm{vol} \%$ ). Two (183-A and $B$ ) of the five cultures (183-A to E) from culture $183-1-1$ produced $0.12 \sim 0.15 \mathrm{vol} \%$ ethanol; the other three produced only $0.04 \mathrm{vol} \%$. These results suggested that at least two kinds of cells were present in culture 1831-1. One strain of culture 138-A was named strain No. 138, and one of culture 183-A was named strain No. 183.

\section{Characterization of the isolates}

The two isolates, strain Nos. 138 and 183, were observed under an electron microscope (Fig. 1). Both strains were rods with flagella. Morphological, physiological and genetic properties of the two isolates are shown in Table I, together with those of $C$. thermocellum ATCC 27405 for reference. The cell shape, spore formation, gram staining, optimum growth temperature, assimilation of carbohydrates, and main products of strain Nos. 138 and 183 were closely similar to those of the type stain, ATCC 27405. The GC content of the chromosomal DNAs isolated from the isolates was almost the same as that in the case of ATCC 27405. Furthermore, the chromosomal DNAs of the two isolates showed high homology

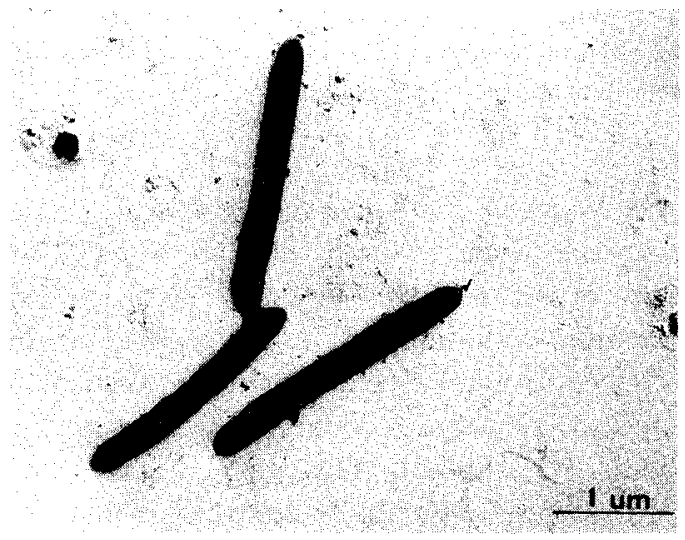

A
$(98 \sim 100 \%)$ with the DNA of the type strain. From these results, strain Nos. 138 and 183 were identified as $C$. thermocellum.

\section{Products from cellulose with the isolates}

Strains Nos. 138 and 183 were grown at $60^{\circ} \mathrm{C}$ for 7 days in DSM medium containing $1 \%$ cellulose, with ATCC 27405 and ATCC 31549 for reference (Table II). Compared with the two type strains, these isolates decomposed more of the cellulose and produced large amounts of reducing sugars in the broth. The two isolates produced more ethanol, acetic acid and lactic acid than the type strains. Strain No. 183 in particular produced much lactic acid and glucose. When strain No. 138 was grown at $60^{\circ} \mathrm{C}$ for 7 days in $\mathrm{K}$ medium containing $6 \%$ cellulose in a jar fermentor ( $1.2 \mathrm{lmedium} / 2 \mathrm{ljar})$, it produced $3.0 \mathrm{~g} / \mathrm{l}$ of ethanol and consumed $75 \%$ of th cellulose added as the sole source of carbon.

\section{Cellulase activities of th isolates}

The CM-cellulase, avicelase and $\beta$-glucosidase activities of the two isolates and the type strain are shown in Table III. The CMcellulase and avicelase activities in the culture broth of strain Nos. 138 and 183 were twice those in the case of ATCC 27405 when the cells were grown for 5 days in $\mathrm{K}$ medium containing
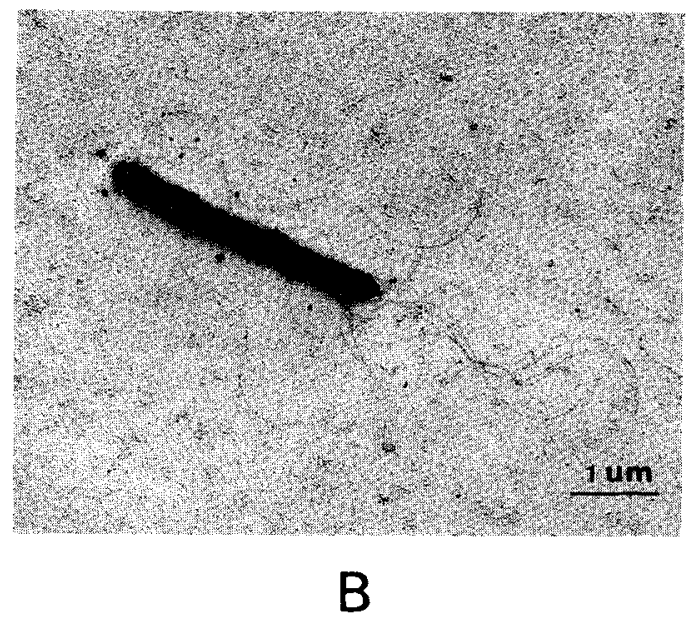

Fig. 1. Electron Micrographs of Platinum-shadowed Cells of the Isolated Strains.

Bar, $1 \mu \mathrm{m}$. A, strain No. 138; B, strain No. 183. 
Table I. Morphological and Physiological Properties of the Isolated Strains

\begin{tabular}{|c|c|c|c|}
\hline \multirow{2}{*}{ Properties } & \multicolumn{3}{|c|}{ Strain No. } \\
\hline & 138 & 183 & $\operatorname{ATCC} 27405^{a}$ \\
\hline Cell shape & Rods & Rods & Rods \\
\hline Size of cells $(\mu \mathrm{m})$ & $0.3 \times 1.5 \sim 4.5$ & $0.3 \times 1.0 \sim 3.0$ & $0.4 \times 1.0 \sim 2.0$ \\
\hline Spore formation & Terminal & Terminal & Terminal \\
\hline Gram staining & Positive & Positive & Positive \\
\hline Optimum temp. & $60 \sim 63$ & 63 & $60 \sim 64$ \\
\hline Optimum pH & $7.5 \sim 8.0$ & $7.5 \sim 8.5$ & $7.5 \sim 8.0$ \\
\hline $\mathrm{GC}$ contents $(\mathrm{mol} \%)$ & 39.0 & 39.2 & 38.1 \\
\hline DNA homology to ATCC 27405 & 100 & 98 & 100 \\
\hline \multirow[t]{6}{*}{ Fermentative sugars ${ }^{b}$} & Fructose & Fructose & Fructose \\
\hline & Glucose & Glucose & Glucose \\
\hline & Cellobiose & Cellobiose & Cellobiose \\
\hline & Cellulose & Cellulose & Cellulose \\
\hline & Salicin & Salicin & Salicin \\
\hline & Sorbitol & Sorbitol & Sorbitol \\
\hline \multirow[t]{3}{*}{ Main products } & Ethanol & Ethanol & Ethanol \\
\hline & Acetate & Acetate & Acetate \\
\hline & Lactate & Lactate & Lactate \\
\hline
\end{tabular}

a C. thermocellum ATCC 27405 ,

b Strain Nos. 138 and 183, and ATCC 27405 could not ferment the following sugars: arabinose, galactose, mannose, rhamnose, ribose, sorbose, xylose, lactose, maltose, melibiose, sucrose, melezitose, raffinose, trehalose, glycogen, inulin, starch, xylan, amygdalin, esculin, adonitol, dulcitol, glycerol, erythritol, inositol and mannitol.

Table II. Products from Cellulose with the Isolated Strains

\begin{tabular}{lcccccc}
\hline Strain No. & \multicolumn{3}{c}{ Product $(\%)$} & & $\begin{array}{c}\text { Consumption } \\
\text { of cellulose } \\
(\%)\end{array}$ \\
\cline { 2 - 7 } & Ethanol & Acetate & Lactate & Glucose & Reducing sugar & 96 \\
\hline 138 & 0.076 & 0.096 & 0.055 & 0 & 0.695 & 81 \\
183 & 0.047 & 0.083 & 0.103 & 0.220 & 0.860 & 14 \\
ATCC 27405 & 0.030 & 0.024 & 0.022 & 0 & 0 & 14 \\
ATCC 31549 & 0.023 & 0.023 & 0.027 & 0 & 0 & 0 \\
\hline
\end{tabular}

a The strains were grown at $60^{\circ} \mathrm{C}$ for 7 days in DSM medium containing $1 \%$ cellulose.

b Clostridium thermocellum.

$1 \%$ cellulose as the sole source of carbon. On the other hand, the $\beta$-glucosidase activity in the cell free extracts of the two isolates was almost the same as that in the case of ATCC 27405. The production of CM-cellulase by strain Nos. 138 and 183, and ATCC 27405, on growth with cellobiose or glucose, was tested. As a result, it was found that they could produce CM-cellulase without inhibition by cellobiose or glucose.
Development of ethanol tolerance of the isolates Strains Nos. 138 and 183, and ATCC 27405 wer grown at $60^{\circ} \mathrm{C}$ for 2 to 3 days in DSM medium containing $1 \%$ cellobiose and various concentrations of ethanol. The two isolates and the type strain could grow in the medium with $1 \%$ ethanol. The three cultures were transferred sequentially to fresh media containing increasing concentrations of ethanol. After seven transfers, all three strains could grow in the presence of high concentrations ( 2.5 to $2.9 \%$ ) of ethanol. 
Table III. Cellulase Activities in the ISOLATED STRAINS

\begin{tabular}{|c|c|c|c|}
\hline \multirow{2}{*}{$\begin{array}{l}\text { Strain } \\
\text { No. }^{a}\end{array}$} & \multicolumn{2}{|c|}{ Supernatant } & \multirow{2}{*}{ Cell-free extract } \\
\hline & CM-Cellulase $\mathrm{e}^{b}$ & Avicelase $^{b}$ & \\
\hline 138 & 5.99 & 1.63 & 2.86 \\
\hline 183 & 4.21 & 1.38 & 2.43 \\
\hline $\begin{array}{c}\text { ATCC } \\
27405^{c}\end{array}$ & 2.64 & 0.78 & 2.30 \\
\hline
\end{tabular}

a The cells were grown in $\mathrm{K}$ medium containing $1 \%$ cellulose for 5 days.

$b$ Unit/mg of protein

c C. thermocellum ATCC 27405.

\section{Cloning of the cel A gene of No. 138}

Chromosomal DNA extracted from C. thermocellum strain No. 138 was digested completely with HindIII. The DNA fragments obtained were electrophoresed on a $1 \%$ agarose gel and then hybridized with the two kinds of probe DNAs described above. Only a single DNA band (about $3.2 \mathrm{~kb}$ ) in an agarose gel hybridized strongly with the probes. The $3.2 \mathrm{kd}$-DNA fragments were eluted from the gel and inserted into the same restriction site of plasmid pUC19: The resulting recombinant plasmids were introduced into $E$. coli strain JM83 cells. Of the plasmids extracted from approximately 800 ampicillin-resistant cells, two plasmids that hybridized strongly with the prove DNAs, designated as pNUC21 and pNUC22, were analyzd. The restriction maps of the HindIII fragments contained in the two plasmids were the same (Fig. 2). The restriction map of the HindIII fragment from strain No. 138 was also almost the same as that containing the cel A gene from ATCC 27405. The HindIII fragment was inserted into the same site of plasmid pBR322 in the ordinary and opposite directions, and the recombinant plasmids obtained were designated as $\mathrm{pNBC1}$ and $\mathrm{pNBC} 2$, respectively.

\section{Expression of cel $A$ genes in $E$. coli}

Recombinant plasmids $\mathrm{pNBC} 1$ and $\mathrm{pNBC} 2$ were introduced into $E$. coli strains $\mathrm{C} 600$ and HB101. The CM-cellulase activity of strain C600 cells carrying either $\mathrm{pNBC1}$ or $\mathrm{pNBC} 2$

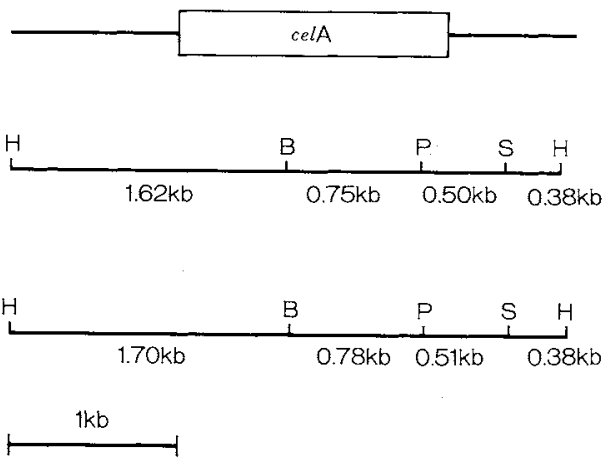

Fig. 2. Restriction Maps of the HindIII Fragments Containing the celA Gene from Clostridium thermocellum ATCC 27405 (a) and from Strain No. 138 (b).

The symbols for restriction endonucleases are: $\mathrm{H}$, HindIII; S, Sau3AI; P, Pst I; and B, BamHI. The molecular sizes (kb) of the linear DNA fragments were determined by agarose gel electrophoresis.

Table IV. CM-Cellulase Activities In E. coli Strains Carrying the celA Gene

\begin{tabular}{rccl}
\hline Strain & Plasmid & $\begin{array}{c}\text { celA } \\
\text { gene }\end{array}$ & $\begin{array}{c}\text { CM-Cellulase } \\
\text { activity }^{b}\end{array}$ \\
\hline E. coli C600 & - & - & 0 \\
C600 & pBR322 & - & 0 \\
C600 & pCT104 & + & 5.52 \\
C600 & pNBC1 & + & 5.49 \\
C600 & pNBC2 & + & 5.07 \\
HB101 & - & - & 0 \\
HB101 & pBR322 & - & 0 \\
HB101 & pCT104 & + & $6.7^{c}$ \\
HB101 & pNBC1 & + & 6.69 \\
HB101 & pNBC2 & + & 7.98 \\
\hline
\end{tabular}

a Strains were grown at $37^{\circ} \mathrm{C}$ in L-broth. For the transformants, ampicillin $(50 \mu \mathrm{g} / \mathrm{ml})$ was added to the L-broth. Late log-phase cells were sonicated and the supernatants were used for assaying CMcellulase.

b Micromoles of glucose generated $/$ hour $/ \mathrm{mg}$ of protein.

c The value reported by Cornet et al. (1983).

was almost the same as that of the cells carrying plasmid pCT104, in which the cel A gene from ATCC 27405 was inserted into the HindIII site of pBR322 in the ordinary direction. This enzyme activity of strain HB101 carrying one of the plasmids was also the same as that of pCT104 (Table IV). 


\section{Discussion}

To obtain cellulose-fermenting thermophiles, we isolated new strains of Clostridium thermocellum, Nos. 138 and 183, from soil and compost, respectively. When cellulolytic bacteria are isolated from nature, there are often coexisting strains, which cannot assimilate cellulose, around the colonies of the cellulolytic strains. We found a coexisting strain growing in culture 183-1-1. This strain could assimilate cellulose weakly. The two isolates, Nos. 138 and 183, which were purified by use of a micromanipulator under anaerobic conditions, were identified as strains of $C$. thermocellum because their morphological and physiological properties were the same as those of the type strain, ATCC 27405. Furthermore, the genetic properties of the two isolates, the GC contents of their chromosomal DNA, and their DNA homology to the chromosomal DNA of the type strain were evidence that they were $C$. thermocellum strains.

The two isolates, however, differed from the type strain in their ability to assimilate cellulose. They could decompose more cellulose than the type strains, ATCC 27405 and ATCC 31549 , and had two times higher CM-cellulase and avicelase activities than the type strain had. The CM-cellulases of the two isolates were constitutively produced and they were also produced without being inhibited by cellobiose or glucose. These results suggested that the two isolates should be useful for the production of cellulases.

Cornet $e t a l{ }^{8)}$ have cloned four cellulase genes from $C$. thermocellum ATCC 27405. Two, cel A and $c e l \mathrm{~B}$, of the four genes have been studied in detail. They reportd that the CM-cellulase activity of $E$. coli HB101 carrying the cel $\mathrm{A}$ gene was higher than that of the same strain carrying the $c e l \mathrm{~B}$ gene. The $c e l \mathrm{~A}$ gene of strain No. 138 was cloned into $E$. coli with reference to the base sequence ${ }^{9)}$ of the cel A gene from ATCC 27405. The restriction map of the HindIII fragment containing the cel A gene from strain No. 138 showed good agreement with that from ATCC 27405. Moreovrer, the expression of the two cel A genes in $E$. coli cells was almost the same. These results also showed that strain No. 138 was a $C$. thermocellum strain. $E$. coli clones carrying plasmid DNA that had the cel A gene inserted in the ordinary and opposite directions exhibited the same CM-cellulase activity; this suggested that a promoter of the cel $\mathrm{A}$ gene from strain No. 138 acted in $E$. coli cells.

If the cel $\mathrm{A}$ gene cloned was introduced into the original strain, No. 138, the CM-cellulase activity of the transformants could be increasd. C. thermocellum transformants carrying high copy numbrs of the cel A gene might be of use for the production of ethanol from the cellulosic biomass.

Acknowledgments. The authors wish to thank Professor J.-P. Aubert, Institut Pasteur, France, for the gift of plasmid pCT104 containing the celA gene of $C$. thermocellum ATCC 27405. They also thank Professor K. Tonomura, University of Osaka Prefecture, and Professor F. Imamoto, Kyoto Pharmaceutical University, for their advice.

This work was supported in part by a Grant-in-Aid from the New Energy Development Organization.

\section{References}

1) M. Taya, H. Hinoki, Y. Suzuki, T. Yagi, M. G. S. Yap and T. Kobayashi, J. Ferment. Technol., 63, 383 (1985).

2) J. Bender, Y. Vatcharapijarn and T. W. Jeffries, Appl. Environ. Microbiol., 49, 475 (1985).

3) D. Freier, C. P. Mothershed and J. Wiegel, Appl. Environ. Microbiol., 54, 204 (1988)

4) N. Ait, N. Creuzet and P. Forget, J. Gen. Microbiol., 113, 399 (1979).

5) E. A. Johnson, F. Bouchot and A. L. Demain, $J$, Gen. Microbiol., 131, 2303 (1985).

6) D. Petre, J. Millet, R. Longin, P. Beguin, H. Girard and J.-P. Aubert, Biochimie, 68, 687 (1986).

7) P. Cornet, D. Tronik, J. Millet and J.-P. Aubert, FEMS Microbiol. Lett., 16, 137 (1983).

8) P. Cornet, J. Millet, P. Beguin and J.-P. Aubert, Bio/ Technol., 1, 589 (1983).

9) P. Beguin, P. Cornet and J.-P. Aubert, J. Bacteriol., 162, 102 (1985).

10) D. V. Garcia-Martinez, A. Shinmyo, A. Madia and A. L. Demain, Eur. J. Appl. Microbiol. Biotechnol., 9, 189 (1980).

11) J. N. Saddler and K. H. Chen, Eur. J. Appl. 
Microbiol. Biotechnol., 16, 99 (1982).

12) N. Kurose, S. Kinoshita, J. Yägyu, M. Uchida, S. Hanai and A. Obayashi, J. Ferment. Technol., 66, 467 (1988).

13) G. L. Miller, Anal. Chem., 31, 426 (1959).

14) H. C. Birnboim and J. Doly, Nucl. Acids Res., 7, 1513
(1979).

15) N. Nelson, J. Biol. Chem., 153, 375 (1944).

16) M. M. Bradford, Anal. Chem., 72, 248 (1976).

17) O. H. Lowry, N. J. Rosebrough, A. L. Farr and R. J. Randall, J. Biol. Chem., 193, 265 (1951). 